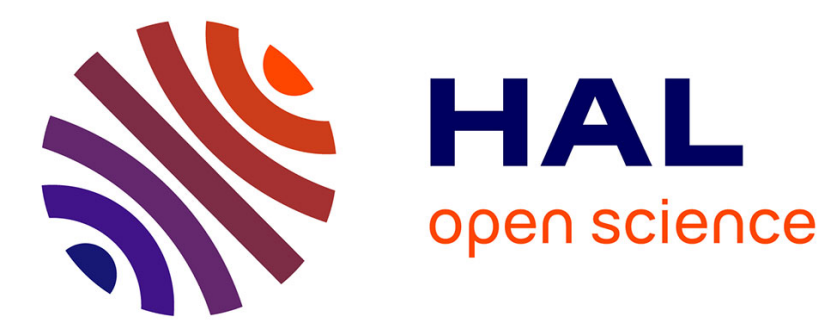

\title{
The consequences of increasing fuel prices on car travel and household budgets
}

\author{
Richard Grimal
}

\section{To cite this version:}

Richard Grimal. The consequences of increasing fuel prices on car travel and household budgets.

TRA2014 - Transport Research Arena, Apr 2014, PARIS, France. 10p. hal-01256971

\section{HAL Id: hal-01256971 \\ https://hal.science/hal-01256971}

Submitted on 15 Jan 2016

HAL is a multi-disciplinary open access archive for the deposit and dissemination of scientific research documents, whether they are published or not. The documents may come from teaching and research institutions in France or abroad, or from public or private research centers.
L'archive ouverte pluridisciplinaire HAL, est destinée au dépôt et à la diffusion de documents scientifiques de niveau recherche, publiés ou non, émanant des établissements d'enseignement et de recherche français ou étrangers, des laboratoires publics ou privés. 


\title{
The consequences of increasing fuel prices on car travel and household budgets
}

\author{
Richard Grimal* \\ French Technical Department of Studies on Transports, Roads and Highways (SETRA) \\ French Institute of Science and Technology for Transport, Development and Networks (IFSTTAR)
}

\begin{abstract}
After decades of growth, average car use per adult suddenly levelled off during the 2000's. This break in trend resulted both from stabilized needs, with the ending transition of the way of life towards a mobility achieved by car, and from increasing financial constraints following the explosion of fuel prices. From a basic model based on motorization rates and an indicator of energetic purchasing power, we show that the stagnation of car travel can be viewed as a lagged reaction to rising fuel prices, the speed of adjustment reflecting the long-run adaptability of household behaviors. As a result of increasing fuel prices, a greater proportion of households has become financially vulnerable, with a higher risk of falling into energetic precarity. The risk has increased most where situations of vulnerability were already concentrated, namely in areas of diffuse urbanization and among low-income households.
\end{abstract}

Keywords: Car travel; fuel prices; car dependence; travel budgets; vulnerability; resilience.

\section{Résumé}

Après des décennies de croissance, le kilométrage moyen circulé par adulte s'est stabilisé pendant la décennie 2000. Cette rupture de tendance résulte à la fois de besoins stabilisés, du fait de l'achèvement du processus de transition de la mobilité vers l'automobile, et de l'augmentation des contraintes financières subies par les ménages résultant de l'explosion des prix des carburants. A partir d'un modèle très simple basé sur le taux de motorisation et le pouvoir d'achat énergétique, on montre que la stagnation de l'usage de la voiture peut être interprétée comme une réaction différée à l'augmentation des prix des carburants, la vitesse d'ajustement reflétant la capacité d'adaptation stratégique à long terme des ménages. La proportion de ménages risquant de basculer dans la précarité énergétique s'est accrue avec l'augmentation des coûts de la mobilité, en particulier là où les situations de vulnérabilité étaient déjà concentrées auparavant, à savoir dans les espaces d'urbanisation diffuse et parmi les ménages modestes.

Mots-clé: Usage de la voiture; prix du carburant; dépendance automobile; budgets-transport; vulnérabilité; résilience.

\footnotetext{
* Richard GRIMAL, French Technical Department of Studies on Transports, Roads and Highways (SETRA), French Institute of Science and Technology for Transport, Development and Networks (IFSTTAR), 14-20 Bld Newton, B524 Cité Descartes, Champs-Sur-Marne, F-77447 MARNE-LA-VALLEE Cedex 2. Tel.: $00 \quad 3311816686$ 26; E-mail address: richard.grimal@ifsttar.fr.
}

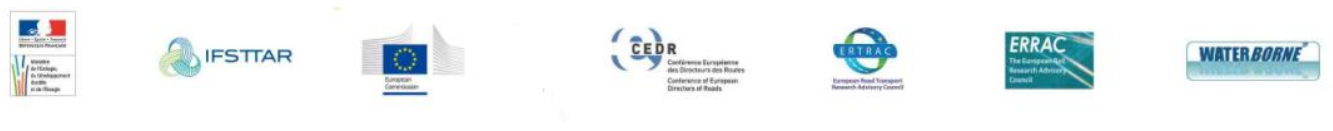




\section{A break in trend in car travel : stabilized needs and increasing financial constraints}

After decades of growth, average car travel has stagnated during the 2000's, in France as in most of developed countries. Reasons for such a break in trend are multiple and were discussed in detail within international studies (Millard-Ball and Schipper, 2010; Goodwin and Van Dender, 2013). The question was generally asked of future levels of car use, suggesting that car travel could have attained a peak to be followed by decline in the future (Goodwin, 2010-2011; Stokes, 2013). In our previous papers (Grimal et al., 2013; Grimal, 2013), we found that such a stagnation was not limited to the largest conurbations, but could also be seen in low-density areas. We found that it could be viewed as the result of partial saturation and a reaction to harder economic conditions, especially the strong increase in fuel prices during the 2000's, as was also shown for instance by Kemel et al. (2010), with a variable sensitivity among households, depending on their residential location and income.

Long-term trends in car travel can be viewed as an interaction between the changing way of life, travel needs, and restrictive constraints. Until the mid-90's, the combination of increasing needs, a changing way of life and releasing constraints, stimulated car travel growth. First, restrictive constraints hindering the expression of latent demand have been declining : higher driving license rates, decreasing motorisation costs, increasing incomes, moderate fuel prices. Simultaneously, travel needs have been increasing with a changing way of life : a greater participation of women to the workforce - generating additional home-to-work trips - and the democratization of leisure travel. The changing way of life also modified the way of expression of travel needs : in particular, the individualization of driving among households, through its extension to women, but also the changing spatial environment - an evolution that was for a part permitted by the diffusion of car ownership, as it released constraints on localization - have been important factors of car travel growth. For given household needs related for example to home-to-work trips - there was an increasing amount of car travel through the individualization of driving and changing land use patterns, resulting in a greater car dependency (Newman and Kenworthy, 1989). Therefore, the changing way of life can be seen as the main driver of growth for car travel, along with the long-run improvement of socio-economic conditions. It led to a relative decline of car travel inequalities depending on income (Collet et al., 2010).

However, from the 2000's, average car travel per adult levelled off in all income groups and areas of residence. It rather declined in urban areas, while slowing down in diffuse areas : the difference in trend could possibly be related to a greater resilience of urban areas, whose inhabitants, especially within core cities, are less cardependent and can turn towards efficient alternatives (transit systems, walking, cycling) when fuel prices are rising. This break in trend corresponds to a changing context, now characterized by stabilized needs, increasing financial constraints and a possibly starting reversal in the way of life. In table 1, the whole period 1977 - 2010 was divided into six subperiods of six years each, except the last period that was only four years. Average values per subperiod were reported for some key determinants of car travel. Reported variables are :

- The average motorization rate of adults (number of cars divided by the number of adults)

- The average simulated driving license rate. Driving license rates were only available in French Car Fleet Surveys, for the period 1993 to 2010, but not in French Household Continuous Surveys. However, as driving license rates depend mainly on the generation of the household head, simulated driving license rates were estimated by applying generational rates calculated from French Car Fleet Surveys to the generational structure of households

- A numeric variable was designed for generation. Generations were defined as five-year brackets and numbered from 1 to 22, the first one being born between 1885 and 1890, the last after 1990. This variable stands for generational renewal, with an increasing diffusion of driving through successive generations, at least among generations born before World War II

- A quadratic effect of generation on car travel was also estimated as the generation effect happens to stabilize in generations born after World War II, and finally decreases in generations born after 1975

- The average employment rate of adults (number of working adults divided by the number of adults)

- The average income per consumption unit (corrected from inflation, in $€ 1984$ ), using the Oxford scale for reasons of continuity with ancient data ( 1 for the first adult, 0.7 for others adults and 0.5 for children less than 14)

- A yearly indicator of fuel price (fuel prices for different types of engines weighted by the structure of the fleet) 
- An indicator of average energetic purchasing power, defined as the average real income per consumption unit divided by a fuel price index.

Table 1. Average values of determinants of car travel by subperiod

Source. French Household Continuous Surveys (1977-1992) and French Car Fleet Surveys (1993-2010)

\begin{tabular}{|c|c|c|c|c|c|c|}
\hline & $1977-1982$ & 1983-1988 & 1989-1994 & $1995-2000$ & $2001-2006$ & $2007-2010$ \\
\hline Average motorization rate of adults & 0.443 & 0.506 & 0.552 & 0.613 & 0.668 & 0.716 \\
\hline Average simulated driving license rate & 0.728 & 0.775 & 0.817 & 0.852 & 0.867 & 0.860 \\
\hline Average generation & 9.6 & 10.8 & 11.9 & 12.7 & 13.5 & 14.5 \\
\hline $\begin{array}{l}\text { Quadratic effect of generation }\left(\alpha \mathrm{C}+\beta \mathrm{C}^{2}\right) \\
\text { on car travel (in } \mathrm{km})\end{array}$ & 12881 & 13277 & 13462 & 13442 & 13092 & 12656 \\
\hline Average employment rate of adults & 0.581 & 0.578 & 0.561 & 0.537 & 0.580 & 0.612 \\
\hline Average real income per consumption unit & 7928 & 8303 & 9348 & 10513 & 10982 & 11225 \\
\hline $\begin{array}{l}\text { Indicator of average real fuel price (base } \\
100 \text { in 1974) }\end{array}$ & 104 & 101 & 90 & 99 & 112 & 126 \\
\hline Indicator of energetic purchasing power & 7623 & 8221 & 10387 & 10619 & 9805 & 8909 \\
\hline
\end{tabular}

The break in trend doesn't come from motorization rates that kept on increasing over the whole period, from 0.443 to 0.716 car per adult between 1977-82 and 2007-10. It doesn't come either from the employment rate of adults that has even been increasing from the 2000's. It rather comes from an exhaustion of generation effects and a reversal of the dynamic of financial constraints that households are subjected to. The generation effect that was estimated through a quadratic form has began declining from the mid-90's, and the simulated driving license rate that has levelled off from the 2000's. On the long-run, motorization rates of adults tend to converge towards driving license rates, suggesting that the current driving license rate around $86 \%$ could also represent an upper threshold for motorization rates. From the late 70 's to the late 2000 's, the motorization rate of licensed adults increased from 60.9 to $83.3 \%$. However, Collet et al. (2013), using logistic curves, simulated a lower threshold of car ownership, by 0.76 car per adult at fuel price levels of 2010, that could be explained by other reasons limiting the diffusion of car ownership, such as a localization in dense metropolitan cities with strong parking difficulties and congestion. Simultaneously, the relaxation of financial constraints has stopped, with strongly increasing fuel prices from the mid-90's and an average income slowing down in the 2000's. Therefore, energetic purchasing power has been decreasing from the mid-90's. Other financial constraints have been increasing during this period, especially the weight of household mandatory expenditures such as housing (Hivert et Madre, 2012). As these expenditures are quite inelastic, they may have contributed to the increased pressure on transport budgets, though there is some evidence from cross-sectional views than trade-offs between transport and housing could be limited (Coulombel et Leurent, 2013).

Finally, the transition of the way of life towards a motorized travel (Wiel, 1999) will soon be complete with the full replacement of generations born before World War II, and greater financial constraints have caused a greater travel rationalization, that could be long-lasting as for the first time the pressure on household budgets has become durable (Kemel, 2008). As a result, the historical movement towards increasing needs for car travel and releasing constraints could have began turning backwards with generation effects now becoming negative in the latest generations, a result that is consistent with the larger international evidence of changing behaviours among the young (for instance Kuhnimof et al., 2012).

\section{A lagged reaction to rising fuel prices}

\subsection{Model specification}

In this section, we implement a basic model of average car travel per adult (in vehicle*kms travelled), based on motorization rates of adults and energetic purchasing power, as defined in section 1 . Three areas of residence are considered : core cities, inner suburbs (in the continuity of core cities, within built-up areas surrounding them), and low-density areas, including outer suburbs (outside built-up areas, defined from a percentage of households whose head is working in the built-up area) and rural areas. In order to assess the predictability of the break in trend in car travel, the model is first estimated on a restricted period (1974 - 1995) preceding it, and then used to forecast average car travel. Three variants of the model are compared : 
- The first one is only based on motorization rates (a)

- In the second one, average car travel depends both on motorization rates and energetic purchasing power (b)

- In the third one, a lagged dependent variable is included to test the assumption of a delay in the reaction to changing travel costs $(\mathcal{C}$. The specification of this model is directly inspired from (Dargay, 2002), though with different exogenous variables.

Hereunder we display respective model specifications :

- (a) $Y t=\beta 0+\beta M M t+\varepsilon t$

- (b) $Y t=\beta 0+\beta M M t+\beta P P P P t+\varepsilon t$

- (C) $Y t=\theta \beta 0+(1-\theta) Y t-1+\theta \beta M M t+\theta \beta P P P P t+\theta \varepsilon t-1$

$Y_{t} \quad$ Average car travel per adult at time $t$

$Y_{t-1} \quad$ Average car travel per adult at time $t-1$

$M_{t} \quad$ Motorization rate of adults at time $t$

$P P_{t} \quad$ Indicator of energetic purchasing power a time $t$

$\varepsilon_{t} \quad$ Disturbance of the model at time $t$

$\beta_{0} \quad$ Intercept

$\beta_{M} \quad$ Parameter associated with motorization rate of adults

$\beta_{P P} \quad$ Parameter associated with average energetic purchasing power

$\theta \quad$ Partial adjustment parameter

Instead of direct exogenous and endogenous variables, the model is estimated on their logarithm, in order to allow a direct interpretation of the parameters as elasticities. The formula (3) is derived from the following :

- $Y t-Y t-1=\theta(Y t-1 * Y t-1)$

- $Y t-1 *=\beta 0+\beta M M t-1+\beta P P P P t-1+\varepsilon t-1$

$Y_{t-1}{ }^{*} \quad$ Desired or potential demand at time $t-1$

$\theta$ can be interpreted as the yearly rate of adjustment to changes in external conditions. It is also the ratio between short-run and long-run elasticities. Distinct estimates are produced for every time-series. Quartiles of income are ordered from low-income to high-income households.

\subsection{Model estimation}

Parameter estimates are figured in table 2, along with $\mathrm{R}^{2}$ statistics. Model (a) already describes quite well car travel growth in all areas and income groups, though with a better goodness-of-fit in low-density areas and medium-income groups. The goodness-of-fit is improved through the introduction of an indicator of energetic purchasing power, better improvements being obtained for core cities and extreme quartiles of income, where the fluctuations of energetic purchasing power have a greater influence on car travel. However, apparent differences in elasticities between areas are caused by different speeds of adjustment to economic conditions. On the longrun, the sensitivity of car travel to the variations of purchasing power is quite independent from the area, but with a different speed of adjustment, that happens to be much faster in low-density areas : $70 \%$ in a single year, against $42 \%$ in inner suburbs and $56 \%$ in core cities. The speed of adjustment also happens to be slower in the $4^{\mathrm{th}}$ quartile and best improvements obtained through the introduction of a lag are for high-income groups. Within other income groups, there is no significant difference between short-run and long-run sensitivity, low-income groups being the most sensitive to financial constraints on the short-run.

Variable interpretations can be given for the value of this parameter. The first one is to consider it as an illustration of the degree of need and emergency of adapting behaviours, either through an increasing car travel, favoured by good economic conditions, given a strong latent demand, or alternatively through the rationalization of car travel, given the level of transport budgets in a context of rising fuel prices. But as it represents the relation between short-run and long-run elasticities, it is also reflecting the variable strategic ability of households to adapt their behaviors through long-run decisions such as a residential relocation or buying more efficient vehicles, beyond short-run emergency measures that can be taken to rationalize travel behaviors and control travel budgets. 
Table 2. Goodness-of-fit and parameter estimates per quartile of income and zone of residence Source. French Household Continuous Surveys (1977-1992) and French Car Fleet Surveys (1993-2010)

\begin{tabular}{|c|c|c|c|c|c|c|c|c|}
\hline & Core cities & $\begin{array}{l}\text { Inner } \\
\text { suburbs }\end{array}$ & $\begin{array}{l}\text { Low-density } \\
\text { areas }\end{array}$ & $\begin{array}{l}\text { 1st } \\
\text { quartile }\end{array}$ & $\begin{array}{l}\text { 2nd } \\
\text { quartile }\end{array}$ & $\begin{array}{l}\text { 3rd } \\
\text { quartile }\end{array}$ & $\begin{array}{l}\text { 4th } \\
\text { quartile }\end{array}$ & $\begin{array}{l}\text { All } \\
\text { included }\end{array}$ \\
\hline \multicolumn{9}{|c|}{ Motorization alone } \\
\hline $\mathrm{R} 2$ & 0.92 & 0.91 & 0.97 & 0.93 & 0.97 & 0.96 & 0.92 & 0.97 \\
\hline$\beta \mathrm{M}$ & 0.98 & 0.95 & 1.25 & 1.15 & 1.20 & 1.06 & 1.11 & 1.09 \\
\hline \multicolumn{9}{|c|}{ Motorization and purchasing power, no lagged dependent variable } \\
\hline $\mathrm{R} 2$ & 0.96 & 0.93 & 0.99 & 0.96 & 0.98 & 0.98 & 0.95 & 0.99 \\
\hline$\beta \mathrm{M}$ & 0.74 & 0.84 & 0.94 & 0.96 & 1.01 & 0.82 & 0.87 & 0.90 \\
\hline$\beta P P$ & 0.31 & 0.19 & 0.40 & 0.41 & 0.25 & 0.31 & 0.30 & 0.29 \\
\hline \multicolumn{9}{|c|}{ Motorization and purchasing power, with a lagged dependent variable } \\
\hline R2 & 0.96 & 0.94 & 0.99 & 0.95 & 0.99 & 0.98 & 0.97 & 0.99 \\
\hline$\theta$ & 0.56 & 0.42 & 0.70 & 0.57 & 0.63 & 0.80 & 0.24 & 0.32 \\
\hline$\beta \mathrm{M}$ & 0.70 & 0.70 & 0.97 & 0.89 & 1.03 & 0.84 & 0.65 & 0.75 \\
\hline$\beta P P$ & 0.36 & 0.37 & 0.37 & 0.45 & 0.23 & 0.31 & 0.63 & 0.36 \\
\hline
\end{tabular}

Keeping in mind these interpretations, we can explain the differences in sensitivities to financial constraints and speeds of adjustment between areas and income groups. Part of the explanation is related to a variable car dependency in relation with localization. For instance, the greater sensitivity of car travel to financial constraints in core cities, can be explained through the ability to move towards alternatives to the car when fuel prices are rising. The difference between short-run and long-run elasticities is also greater within conurbations, as inhabitants of these areas face a lower degree of necessity for car travel and the emergency of adapting behaviours in case of rising fuel prices is weak, given low transport budgets. Simultaneously, they have greater opportunities to move towards alternatives to the car on the long-run. On the contrary, inhabitants of low-density areas are less sensitive to financial constraints on the long-run, as they have a strong necessity for car travel and few opportunities to adapt their behaviours beyond emergency measures. Differences between income groups are also partly explained by effects of localization, as high-income groups often live in densely populated, transit-oriented areas, while middle-class households often live in car-dependent areas. The degree of necessity of additional car travel is also weaker in high-income groups as they are closer to saturation, such as the sensitivity to the increasing cost of mobility, given higher financial resources. On the other hand, they may have a greater strategic ability on the long-run, for instance through professional and residential mobility, or the removal of superfluous leisure trips. On the contrary, middle-class and low-income households show a weak ability to adjust their behaviors on the long-run, beyond immediate measures.

\subsection{Forecasting car travel}

Models, after being estimated, are used to forecast car travel, in particular on the period 1995-2010, characterized by strongly increasing fuel prices. Simulation results are pictured in figure 1 for all areas and for the $4^{\text {th }}$ quartile of income. The model based on motorization alone simulates quite well long-term trends until 1994. Predictions are very good in low-density areas where car travel growth is almost linear and quite unsensitive to fuel price fluctuations (the oil shocks of the late 70's and the oil counter-shock of the mid-80's). Then, from the mid-90's to the early 2000 's, predictions remain quite good in low-density areas, where the slowdown of car travel from the mid-90's partially corresponds to a temporary slowdown in motorization rates. On the contrary, in urban areas, real car travel growth is increasing faster than predicted, in particular in core cities, despite an important slowdown of motorization rates. But the most important disconnection between car travel and motorization is beginning from the 2000's, where despite a strong increase in motorization rates in all areas, average car travel stagnates or is even decreasing. Obviously, this model doesn't reproduce fluctuations of car travel related to financial constraints, that happen to be of greater amplitude in urban areas than in lowdensity areas, nor explains the break in trend in behaviours starting from the 2000's. 


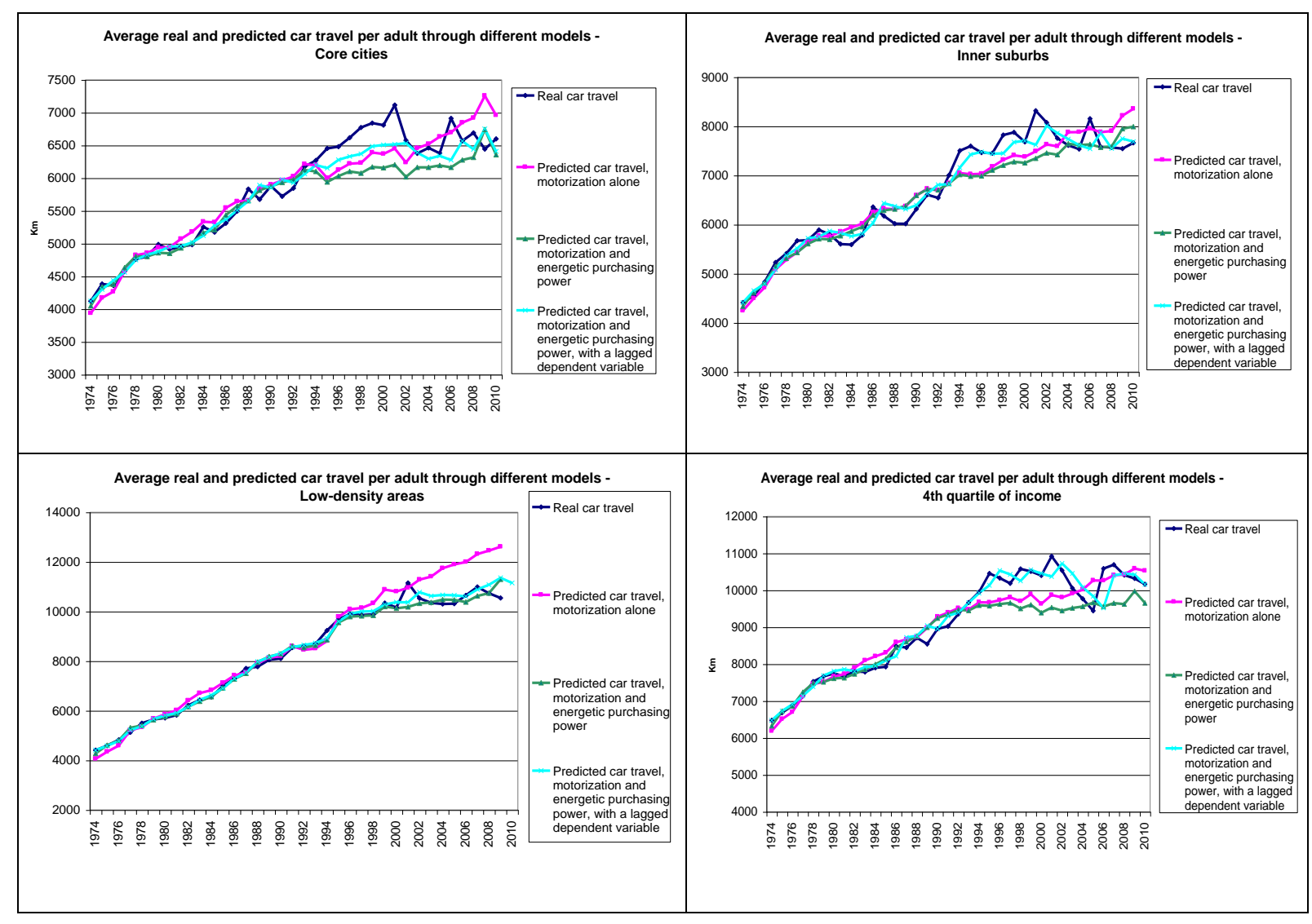

Fig. 1. Average real and simulated car travel through models (1), (2) and (3)

(a) core cities; (b) inner suburbs; $\odot$ low-density areas; (d) $4^{\text {th }}$ quartile.

The model taking into account energetic purchasing power anticipates a slowdown in car travel growth in all areas. Predictions become almost perfect in low-density areas : the date of the breakdown perfectly corresponds to the realty, as well as average values of car travel. In core cities, the model predicts a slowdown from 1993, while the realty rather corresponds to a break in trend from 2001 : it looks like behaviors have not changed continuously in reaction to increasing fuel prices, but rather after the peak of 2000 that must have represented some psychological threshold. The same phenomenon is observable in inner suburbs. The introduction of a lag doesn't have an important effect on predictions relative to low-density areas. This result is consistent with what we found about the speed of adjustment to external conditions that is almost instantaneous in those areas. On the contrary, within conurbations, predictions are significantly improved through the introduction of a lag. Within core cities, predictions become almost perfect from 2002, with a predicted date of the break in trend now almost corresponding to the truth. Within inner suburbs, predictions are almost perfect from the mid-90's, with a slowdown followed by a slight decline from 2002. Finally, predictions relative to high-income groups project some light on phenomenons of saturation. The break in trend happens sooner, from 1995 ; from then, car travel has known important fluctuations. The model based on motorization alone already correctly anticipates the stagnation of car travel from the mid-90's, illustrating a greater proximity to the saturation of demand. Predictions are not much improved through an indicator of purchasing power, but a very substantial improvement is brought through a lag, the period starting from the mid-90's then being almost perfectly described.

To conclude this section, the assumption of a lagged reaction to rising fuel prices seems to hold : almost instantaneous in low-density areas, this reaction was rather progressive in urban areas, suggesting that while this reaction may be temporary and limited in low-density areas, it may recover strategic long-run adjustments of behaviors within conurbations. In core cities and among high-income groups, this reaction was amplified by a quite long pause in motorization rates, that may now be close to saturation. 


\section{The rise of fuel poverty}

\subsection{Data and methodology}

In this section, we assess the effect of rising fuel prices on energetic precarity, depending on income and zone of residence. A normative approach is designed to determine a threshold of vulnerability, inspired from Nicolas et al. (2012). However, in this study, the calculation of this threshold is based only on fuel expenditures rather than on total travel costs. For reasons of data availability, fuel budget shares were calculated only on French Car Fleet Surveys, from 1993 to 2010. Household fuel consumptions are obtained as the sum of fuel consumptions of household vehicles, that are themselves calculated from unitary vehicle consumptions (in 1/100 $\mathrm{km}$ ) combined with reported travelled distances for every vehicle. Household fuel budgets are then estimated as the product of vehicle fuel consumptions per fuel prices by type of motorization (gas/diesel/GPL). Fuel budget shares are then obtained by dividing household fuel budgets by household incomes. Indexes of inflation are used to take into account the erosion of fuel budgets in real terms.

\subsection{Impacts of rising fuel prices on household budgets and the rationalization of car travel}

The real dynamic of car travel is then compared with a theoretical view into which car travel is supposed to derive from several factors :

- The dynamic of fuel prices in current $€$

- Changing types of motorization, mainly the gradual replacement of gas engines by diesel engines

- The increasing energetic efficiency of vehicles, for a given type of motorization, expressed in $\mathrm{km} / \mathrm{l}$

- Inflation

- The standard of living, expressed in constant $€$ per consumption unit

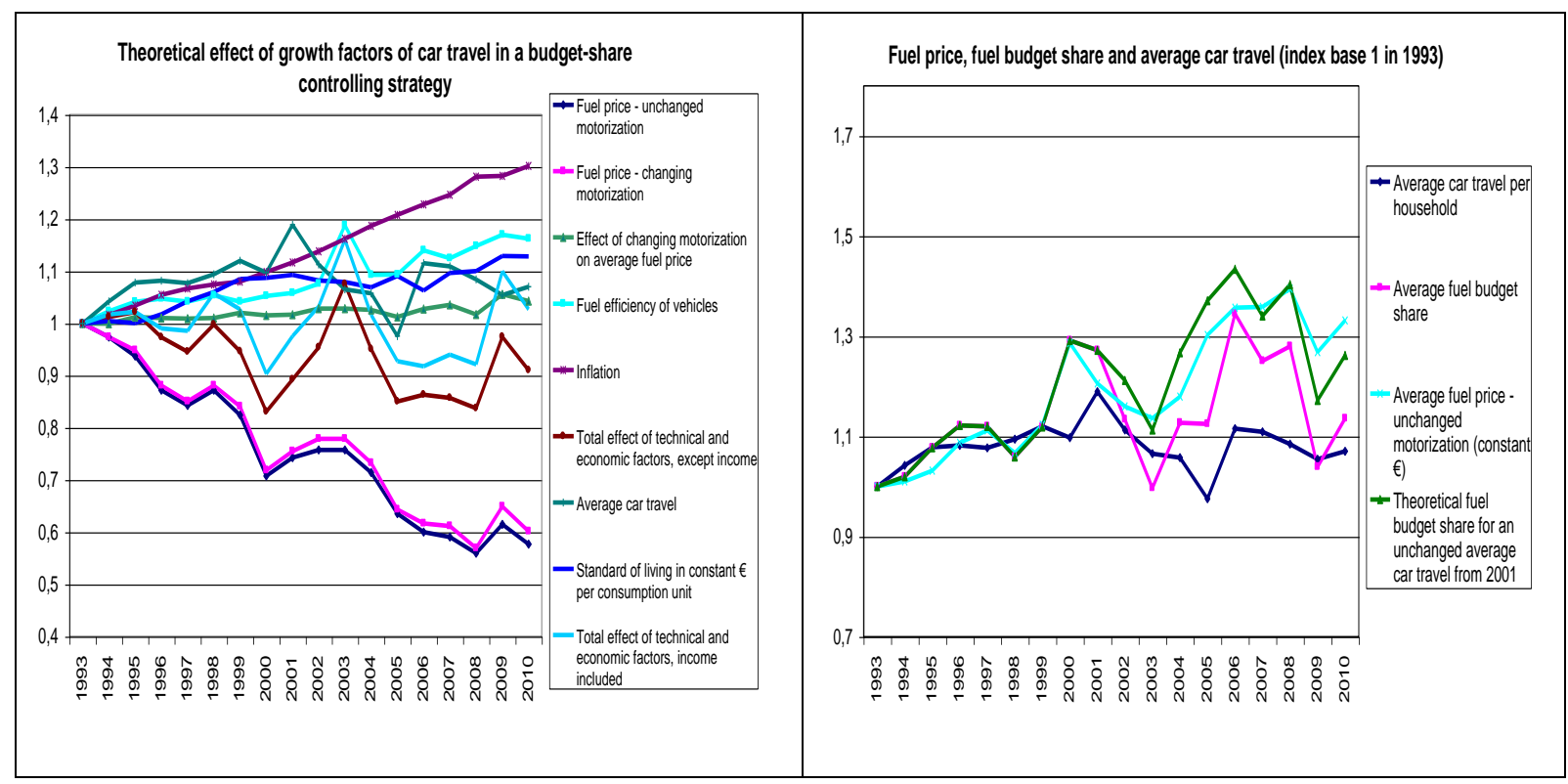

Fig. 2. (a) Theoretical effect of growth factors on car travel in a budget-share controlling strategy

(b) Fuel price, fuel budget share and average car travel (index base 1 in 1993)

Theoretical average car travel for a given year is calculated under the assumption of a strategy into which households try to maintain their fuel budget share constant. This strategy looks quite realistic when considering average travel budget shares, that maintain at a relatively stable level of $15 \%$, according to Household Budget Surveys. Under this assumption, factors mentioned above can be considered as theoretical growth components of car travel, that are pictured in Fig. 2 (a). Technical and economic factors, income included, represent a potential growth of $3.1 \%$ between 1993 and 2010, a result not far from the real evolution that was of $7 \%$. Therefore, the assumption of a budget share-controlling strategy holds quite well when considering long-run trends. However, 
fuel price fluctuations have been very important during this period, with two peaks in 2000 and 2006 , corresponding each time to the threshold of an average 4.6 to $4.8 \%$ fuel budget share. As strategies to rationalize car travel are starting from these peaks, we can assume this threshold to stand either for objective financial constraints that have caused a feeling of greater vulnerability among households, or for some psychological barrier in the willingness-to-pay of car users. We can also see from fig. 2. (b) that budget shares have followed the fluctuations of fuel prices, meaning that households did not manage to control their budget shares, that have for instance increased from $3.6 \%$ to $4.9 \%$ between 2003 and 2006. Indeed, fuel price fluctuations were too fast to allow households to adapt : they only managed to limit the increase of fuel budget shares. Over the whole decade, the benefit in fuel budget shares obtained through car travel rationalization can be estimated at $0.46 \mathrm{pts}$.

\subsection{An increasing vulnerability, especially in areas of diffuse urbanization and among low-income households}

Finally, we examine the effects of increasing fuel prices on household vulnerability, and whether these effects have been homogeneous or not between zones of residence and income groups. In the first definition, vulnerability is supposed to depend only on fuel budget shares. Inspiring from Nicolas et al. (2012), a threshold of vulnerability was empirically determined at $7 \%$, corresponding to a drop out in the distribution of budget shares. Using this threshold, approximately corresponding to the double average budget share, $18.7 \%$ of households can be considered vulnerable. In the second definition, budget shares are crossed with a poverty threshold - that is estimated as half median income - as a given budget share doesn't recover the same risk of falling into fuel poverty depending on household income :

- If fuel budget share is inferior to $2 \%$, the household is not considered vulnerable to fuel prices

- If it stands between $2 \%$ and $10 \%$, vulnerability depends on income. The household is considered vulnerable if the remaining income after deduction of fuel expenditures is inferior to the poverty threshold

- If it is higher than $10 \%$, the household is considered vulnerable, whatever its income

The second definition is more restrictive and focused on low-income households that are identified as representing a greater risk of energetic precarity, with lower rates of vulnerability as a consequence. It could be used to prioritize public help. Of course, it is also open to criticism, as it is omitting households that have limited fuel expenditures because they don't have access to a car, either for financial reasons or because they never had a driving license, that could nonetheless be socially and economically fragilized through this deficiency (Pochet et Nicolas, 2007). However, these households will be rather considered as already excluded from mobility, vulnerability being defined as a risk of falling into a precarious mobility or difficult financial situation consecutive to high travel costs.

Depending on fuel prices, the proportion of vulnerable households has fluctuated from 10 pts, with two peaks at $27.2 \%$ and $26.4 \%$ in 2000 and 2006, to be compared respectively to $16.7 \%$ and $18.3 \%$ in 1993 and 2003. Though temporary, the impact of fuel price volatility on energetic precarity was thus far from being negligible. With the more restricted definition, it fluctuated between 10 and $15 \%$. Fuel budget shares have always been higher in low-density areas - between 5 and $6.5 \%$ - than in conurbations, where they fluctuated between 3 and $4.5 \%$, a result that is consistent with the literature (Orfeuil and Polacchini, 1999), and explained by higher transport costs combined with a lower income on average. It is also in low-density areas, that were already the most vulnerable areas in 1993, that the proportion of vulnerable households has increased the most, for instance from $24 \%$ to $37.4 \% \%$ between 1993 and 2001 - according to the first definition of vulnerability. In urban areas, it progressed from $12.7 \%$ to more than $20 \%$ during the same period. Therefore, though vulnerability has increased everywhere, the gap between urban areas and low-density areas got deeper.

The impact of rising fuel prices was also much different depending on income. Obviously, fuel budget shares always have been much higher among low-income households : from $6.4 \%$ to $2.8 \%$ in 1993 from the $1^{\text {st }}$ to the $4^{\text {th }}$ quartile of income, from $7.6 \%$ to $2.9 \%$ in 2010 . Besides, the difference in budget shares is increasing in periods of high fuel prices : fuel shares have been quite stable in the $4^{\text {th }}$ income group, fluctuating between 2.8 and $3.4 \%$, while fluctuating between 6.4 and $9.3 \%$ in the $1^{\text {st }}$ income group. Reasons for a lower volatility among high-income households are a higher income denominator, but also a higher growth of average income, compensating the increase in fuel prices. As a result, the rate of vulnerability was much more volatile among low-income households, from 33.8 to $47.4 \%$ - with the large definition -, than among high-income households from 4.2 to $10.8 \%$. 


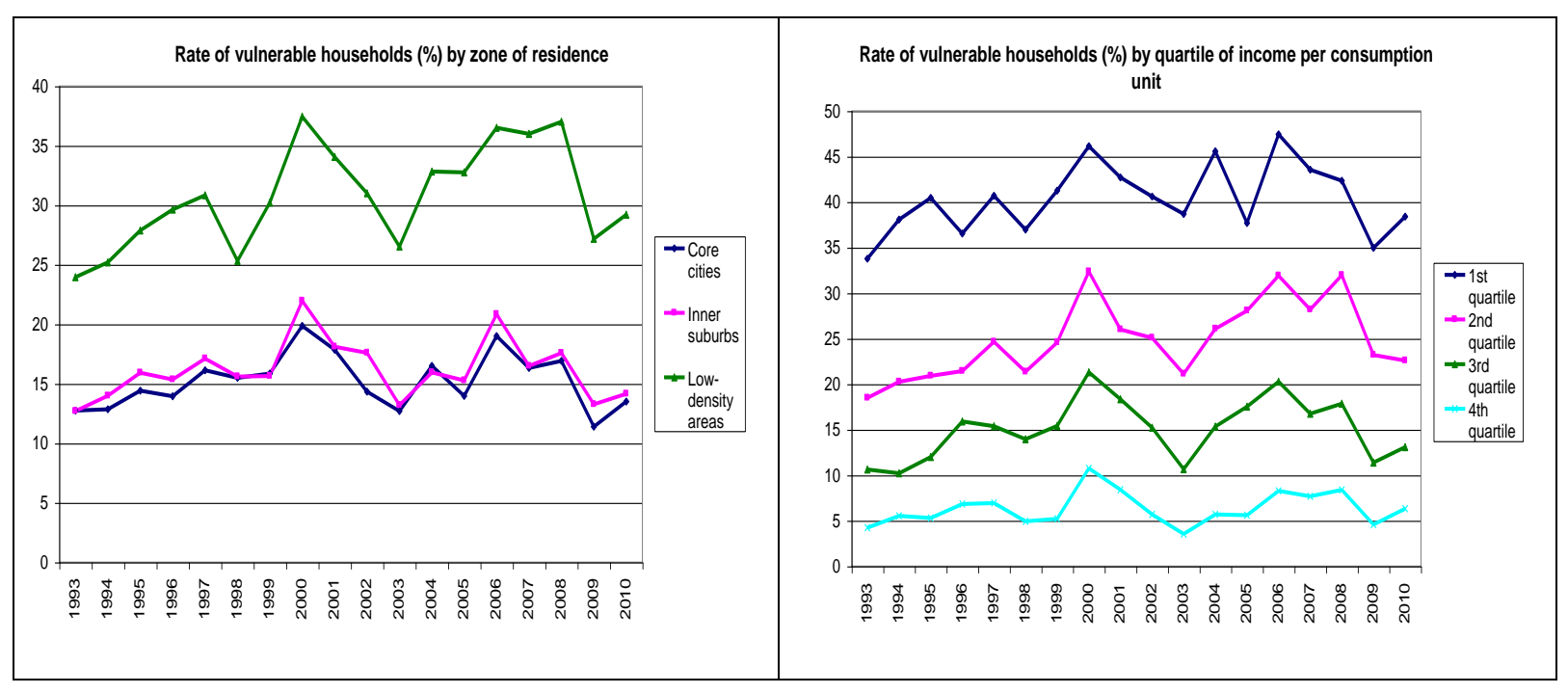

Fig. 3. Rate of vulnerability of households according to the unrestricted definition

(a) By zone of residence ; (b) By quartile of income

Therefore, the risk of falling into energetic precarity increased most where it was already the highest, within lowdensity areas and among low-income households, as is illustrated by figures 3. (a) and 3. (b). However, public policies aiming at preventing or fighting against energetic precarity should not be limited to areas of diffuse urbanization : given urbanization rates, almost half of vulnerable households live within conurbations, distributed equally between core cities and inner suburbs. Public help should in fact uppermost target lowincome households, where most situations of vulnerability are concentrated : the $1^{\text {st }}$ quartile gathers $66 \%$ of vulnerable households, among which $34.3 \%$ are living in low-density areas, $17.3 \%$ in core cities, $14.3 \%$ in inner suburbs. Another important group would be households from the $2^{\text {nd }}$ quartile living in low-density areas, gathering $11.5 \%$ of vulnerable households.

However, this approach doesn't take into account the probably variable resilience of populations and territories, depending on transport alternatives and land use patterns, that may finally provide a relative benefit to dense, functionally-mix and central areas. One can expect this better resilience to reinforce social competition to access core cities and their close suburbs. High-income households will probably be in a better position to adapt to this transition through residential mobility and the acquisition of more efficient vehicles. Thinking about policy implications, a central issue will be the ability of public decision makers to offer additional transit supply, pedestrian and cycling facilities and to manage the overcrowding of public transport that has already become a reality in several big cities. Adaptations of transport supply need time while the effects of an energetic shock can be very sudden. In this scenario, the pressure on fuel budgets will represent a strong incentive for the renewal of the car fleet towards more efficient vehicles, stimulating the research and technical progress. But on the other hand, substantial social difficulties will rise and the quality of life will be degraded.

\section{References}

Collet, R., Boucq, E., Madre, J-L. \& Hivert, L. (2010). Dynamique à long terme des inégalités entre les ménages concernant l'automobile en France. In Pétrole, mobilité, CO2 : les politiques publiques et l'automobilité face à la variation des prix du pétrole. Crozet (Ed.), PREDIT 4 - DRI, 14 p.

Collet, R., Madre, J-L. et Hivert, L. (2013). Vers quels plafonds pour la motorisation et l'usage de la voiture ? Economie et Statistiques, 457 - 458.

Coulombel, N. et Leurent, F. (2013). Les ménages arbitrent-ils entre coût du logement et coût du transport ? Une réponse dans le cas francilien. Economie et Statistiques, $457-458$. 
Dargay, J. (2002). Determinants of car ownership in rural and urban areas : a pseudo-panel analysis. Transportation Research Part E : Logistics and Transportation Review, 38, 5, 351 - 366.

Goodwin, Ph., (2010-2011). Peak Car - Series of five articles. Local Transport Today, London.

Goodwin, Ph., Van Dender, K. (2013). Peak car - Themes and issues. Transport Reviews, special issue on peak car, 33, 3, $243-254$.

Grimal, R., Collet, J.L. \& Madre, J. L. (2013). Is the stagnation of individual car travel a general phenomenon in France ? A Time-Series analysis by zone of residence and standard of living. Transport Reviews, special issue on peak car, 33, 3, $291-309$.

Grimal, R. (2013). La stagnation de l'usage de la voiture en France dans les années 2000 : une analyse par génération et zone de résidence. In Actes du colloque francophone de socio-économie des transports, Rio de Janeiro.

Hivert, L. et Madre, J-L. (2012). L'adaptation des ménages aux hausses du prix des carburants. In La mobilité urbaine des années 2000, éditions CERTU.

Kemel, E. (2008). Influence de la hausse récente des prix des carburants sur la consommation automobile des ménages - analyse portant sur la France entière sur la période 1999 - 2006. Master Transports-EspacesRéseaux, Université Lumière-Lyon II.

Kemel, E., Collet, R. \& Hivert, L. (2010). How do French motorists react to a multi-annual fuel price increase ? - An econometric analysis based on 1999-2007 panel data. Proceedings of the $27^{\text {th }}$ Conference of Applied MicroEconomics, Angers.

Kuhnimof, T., Armoogum, J., Buehler, R., Dargay, J., Martin Denstadli, J. \& Yamamoto, T. (2012). Men shape a downward trend in car use among young adults - Evidence from six industrialized countries. Transport Reviews, 32, 6, 761 - 779 .

Millard-Ball, A., Schipper, L. (2010). Are we reaching peak travel ? Trends in Passenger Transport in Eight Industrialized Countries. Transport Reviews, 31, 3, 357 - 378.

Newman, P.W.G. and Kenworthy, J.R. (1989). Cities and automobile dependence. An international sourcebook. Gower Technical, Sydney.

Nicolas, J.-P., Verry, D. \& Vanco, F. (2012). Utiliser la voiture pour se déplacer au quotidien : taux d'effort et vulnérabilité des ménages face à l'augmentation du prix des carburants. Revue d'Economie Régionale et Urbaine, 1, 5 - 30 .

Orfeuil, J.P, Polacchini, A. (1999). Les dépenses des ménages franciliens pour le logement et les transports. Recherche Transports Sécurité, 63, 31 - 46.

Pochet, P., Nicolas, J-P. (2007). Social inequalities in access to cars and daily mobility : the French experience. International Conference on Public Transport and Urban Citizenship : Making Dublin the capital of Ireland.The Policy Institute, Trinity College, Dublin.

Stokes, G. (2013). The prospects for future levels of car access and use. Transport Reviews, special issue on peak car, 33, 3, $360-375$.

Wiel, M. (1999). La Transition urbaine ou le passage de la ville pédestre à la ville motorisée. Editions Mardaga. 